\title{
KONTRIBUSI PENGETAHUAN AWAL DAN MOTIVASI BELAJAR TERHADAP MISKONSEPSI SISWA PADA PEMBELAJARAN FISIKA
}

\author{
Aloisius Harso'), Daniel Wolo'1), Insar Damopolii²) \\ 1)Pendidikan Fisika, Fakultas Keguruan dan IImu Pendidikan, Universitas Flores, Flores, Indonesia \\ 2)Pendidikan Biologi, Fakultas Keguruan dan Ilmu Pendidikan, Universitas Papua, Papua Barat, Indonesia \\ Corresponding author: Aloisius Harso \\ E-mail: harsoalo4@gmail.com
}

Diterima 08 November 2021, Direvisi 18 November 2021, Disetujui 18 November 2021

\begin{abstract}
ABSTRAK
Penelitian ini bertujuan (1) menganalisis kontribusi pengetahuan awal terhadap miskonsepsi siswa dalam pelajaran fisika, (2) menganalisis kontribusi motivasi belajar terhadap miskonsepsi siswa dalam pelajaran fisika, dan (3) menganalisis kontribusi pengetahuan awal dan motivasi belajar siswa terhadap miskonsepsi yang dialami siswa dalam pelajaran fisika. Penelitian korelasional adalah jenis penelitian yang dilakukan dalam riset ini. Total 222 siswa SMA kelas X pada semester genap tahun 2019/2020 di Kecamatan Nangapanda adalah populasi pada penelitian ini. Total 85 sampel siswa dipilih secara teknik acak proposional (Propotional random sampling). Data riset dikumpulkan melalui tes pemahaman konsep fisika untuk mengkalkulasikan pengetahuan awal dan miskonsepsi, dan motivasi belajar dikumpulkan melalui kuisioner motivasi belajar. Data yang dianalisis regersi dalam penelitian ini adalah pengetahuan awal, motivasi dan miskonsepsi fisika siswa. Hasil penelitian menunjukkan (1) terdapat kontribusi pengetahuan awal terhadap miskonsepsi sebesar $54.6 \%(p<0.05)$, (2) terdapat kontribusi motivasi belajar terhadap miskonsepsi sebesar $58.7 \%(p<0.05)$, dan (3) terdapat kontribusi pengetahuan awal dan motivasi belajar terhadap miskonsepsi sebesar $68.5 \%(p<0.05)$. Kesimpulan penelitian ini adalah terdapat kontribusi pengetahuan awal dan motivasi terhadap miskonsepsi siswa dalam pembelajaran fisika.
\end{abstract}

Kata kunci: Pengetahuan awal; Motivasi; Miskonsepsi; Pembelajaran fisika

\begin{abstract}
This study aims (1) to analyze the contribution of prior knowledge to students' misconceptions in physics, (2) to analyze the contribution of learning motivation to students' misconceptions in physics, and (3) to analyze the contribution of prior knowledge and students' motivation to misconceptions experienced by students in physics learning. Correlational research is the type of research conducted in this research. A total of 222 class X high school students in the even semester of 2019/2020 in Nangapanda District are the population in this study. A total of 85 students were selected as the sample by using the proportional random sampling technique. Research data were collected through a physics concept understanding test to calculate prior knowledge and misconceptions, and learning motivation was collected through a learning motivation questionnaire. The data analyzed by regression in this study were students' prior knowledge, motivation, and physics misconceptions. The results showed (1) there was a $54.6 \%$ contribution of prior knowledge to misconceptions $(p<0.05)$, (2) there was a $58.7 \%$ contribution of learning motivation to misconceptions $(p<0.05)$, and $(3)$ there was a contribution of prior knowledge and learning motivation. against misconceptions by $68.5 \%(p<0.05)$. This study concludes that prior knowledge and motivation contribute to students' misconceptions in physics learning.
\end{abstract}

Keywords: Prior knowledge; Motivation; Misconception; Physics learning

\section{PENDAHULUAN}

Perkembangan ilmu pengetahuan dan teknologi telah membawa dunia ke era industri 4.0. Era yang mampu memberikan peluang sekaligus tantangan bagi umat manusia. Agar era ini menjadi peluang bagi generasi baru maka perlu dibekali dengan berbagai pengetahuan dan keterampilan. Proses pematangan pengetahuan dan keterampilan akan tercapai melalui proses belajar. Kegiatan belajar ialah usaha yang dilakukan seseorang dan berdampak pada suatu perubahan tingkah lakunya secara keseluruhan, perubahan pengetahuan dan sikap sebagai hasil pengalamannya orang itu dalam berinteraksi dengan lingkungannya (Slameto, 2003).

Hasil belajar yang dicapai oleh siswa Indonesia hingga saat ini secara umum belum 
optimal. Indonesia menduduki peringkat 71 dari 129 negara berdasarkan data yang dihimpun oleh United Nation Educational, Scientific, and Cultural Organization (UNESCO) yang dirilis pada November tahun 2008. Data hasil Survey Trend International Mathematics ScienceStudi 2007 menginformasikan bahwa kemampuan IPA siswa berada pada peringkatke 41 dari 48 negara (TIMSS, 2007). Upaya yang dilakukan pemerintah Republik Indonesia untuk meningkatkan kualitas pendidikan yang ada di Indonesia yakni melalui proses pembaharuan kurikulum pendidikan, memberikan berbagai jenis pelatihan pada guru-guru, peningkatkan sarana dan prasarana di sekolah-sekolah, serta berbagai program lainnya untuk peningkatan kemampuan keprofesionalan guru. Namun dalam mengatasi masalah mutu pendidikan di Indonesia usaha-usaha tersebut belum optimal. Khusus bidang Sains, penyebab utama rendahnya hasil belajar yang dicapai oleh siswa adalah kondisi pembelajaran yang kurang memperhatikan prakonsepsi yang dimiliki siswa dan berdampak pada timbulnya miskonsepsi (Bhure, Welu, See, \& Ota, 2021; Nurmaya, Susilawati, Zuhdi, \& Hikmawati, 2021; Ruto, Mema, Nduru, \& Ota, 2021; Sadia, 1997). Para ahli mendefinisikan miskonsepsi yakni "strongly held cognitive structures that are different from the accepted understanding in a field and that are presumed to interfere with the acquisition of the knowledge" (Hammer, 1996); suatu pandangan yang naif yang tidak bisa diterima secara ilmiah (Brown, 1992), keyakinankeyakinan yang tidak diterima menurut metode ilmiah (Eryilmaz, 2002), pemahaman yang salah (Perkins \& Simmons, 1988), pengetahuan intuisi (Vosniadou, loannides, Dimitrakopoulou, \& Papademetriou, 2001), kerangka berpikir alternatif (Carey, Evans, Honda, Jay, \& Unger, 1989).

Dari telaah beberapa literatur menunjukan bahwa semua siswa telah mengalami miskonsepsi baik pada jenjang SD, SMP, SMA bahkan hingga pada level perguruan tinggi. Dalam ilmu Fisika hampir semua pokok bahasan terjadi miskonsepsi yakni mekanika, termodinamika, optik, teori relativitas, fisika kuantum dan astronomi (Kuczmann, 2017), gaya dan gerak (Eryilmaz, 2002), dinamis (Harso, 2018), optika geometris (Saputri \& Nurussaniah, 2015), kinematika gerak (Sutrisno, 2019) dan banyak materi fisika lainnya yang ada diajarkan di sekolah. Umumnya, sumber penyebab munculnya miskonsepsi siswa adalah buku referensi; cara komunikasi guru saat menginformasikan materi; orang tua siswa, kelompok belajar siswa; budaya siswa; media, eksperimen pribadi siswa (Patil, Chavan, \& Khandagale,
2019). Lebih lanjut miskonsepsi selain terjadi pada siswa, guru juga mengalami miskonsepsi serta ditemukan dalam buku teks fisika (Suparno, 2013).

Penyebab miskonsepsi bersumber dari dalam diri siswa itu sendiri misalnnya besarnya motivasi dan pengetahuan awal dimiliki (Turkmen \& Usta, 2007). Memperoleh informasi dan membangun atau mengkonstruk pengetahuan baru dilakukan secara aktif oleh siswa dalam segala usia dengan penerapan berbagai pembelajaran (Chan, Septia, Febrianti, \& Desnita, 2021; Dahar, 2011). Pengetahuan tersebut timbul sebagai akibat adanya interaksi dengan lingkungan sekitar. Lebih lanjut Suparno, (2013) menyatakan bahwa konsep atau pengetahuan awal siswa tentang sebuah materi pelajaran sebenarnya telah ia miliki sebelum belajar pada kelas formal, tetapi pengetahuan awal siswa ini kebanyakan mengandung miskonsepsi.

Menurut Duit, (1996), merubah konsep yang dimiliki siswa harus memperhatikan empat kondisi, yaitu a) adanya ketidakpuasan dengan gagasan yang ada, b) konsep yang baru harus dapat dimengerti, c) konsep harus terlihat masuk akal, d) konsep yang baru harus penuh dengan keberhasilan. Siswa biasanya tidak mampu dan menolak untuk merubah konsep yang telah mereka miliki, karena siswa lebih tertarik dengan konsep mereka dan gagal menemukan keuntungan dari konsep yang baru tersebut. Perubahan konseptual ini sangat tergantung oleh besarnya motivasi siswa untuk belajar. Artinya, diperlukan motivasi yang tinggi untuk mendukung perubahan konsepsi siswa agar miskonsepsi tidak terjadi secara terus menerus. Siswa akan memiliki energi yang banyak untuk memulai dan melakukan kehgiatan belajar jika ia memiliki motivasi yang kuat untuk belajar (Avila \& Genio, 2020; Kurniawan, Damopolii, \& Sirait, 2021; Yurida, Damopolii, \& Erari, 2021). Ini berarti kurangnya motivasi belajar siswa sangat berdampak proses belajarnya, sehingga peluang siswa untuk mengalami miskonsepsi menjadi lebih besar.

Hasil belajar siswa akan baik dan optimal kareanya adanya pengetahuan awal. Pengetahuan awal memegang peranan untuk membangun secara optimal pemahaman siswa terhadap suatu objek yang mereka pelajari. Proses pembelajaran akan berjalan lancar jika siswa memiliki pengetahuan awal yang cocok dengan pengetahuan baru yang dipatkan dalam pembelajaran. Sebaliknya, ketidaksesuaian pengetahuan awal yang dimiliki siswa dengan pengetahuan yang baru ia peroleh, maka terjadilah miskonsepsi yang menyebabkan hambatan dalam pembelajaran (Santyasa, 
2012). Disini dapat dikatakan bahwa miskonsepsi masih ditemukan pada pengetahuan awal siswa. Diperlukan sebuah penelitian untuk mengkaji bagaimana pengetahuan awal ini berkontribusi terhadap besarnya miskonsepsi siswa, khususnya pada pembelajaran fisika.

Selain itu, miskonsepsi bisa terjadi karena ketidakhadiran siswa dalam mengikuti pelajaran di kelas secara kontinu. Karena ada konsep-konsep yang terlewatkan padahal konsep-konsep tersebut ada keterkaitannya dengan materi selanjutnya. Tidak ada upaya untuk belajar secara mandiri atau berdiskusi dengan teman yang sudah memahami konsep tersebut. Bila ada waktu untuk berkumpul dengan teman, aktifitas yang sering dilakukan adalah bermain bersama teman-temannya, bermain dengan permainan elektronik, menonton televisi dan lainnya (Turkmen \& Usta, 2007). Miskonsepsi siswa dapat direduksi melalui pemberian motivasi, karena dengan memotivasi siswa maka mereka akan merespon konsepsi ilmiah yang terbentuk.

Motivasi secara umum didefinisikan sebagai gaya, rangsangan, atau pengaruh yang menyebabkan seseorang untuk bertindak atau merespon (Baransano, Yohanita, \& Damopolii, 2017; Raiman, Liu, \& Wolo, 2021; Yenilmez \& Cemrek, 2008). Bila seseorang tidak memiliki motivasi belajar maka konsep-konsep baru yang diperoleh dari aktifitas pembelajaran terbentuk akan sulit diterima karena konsepkonsep lama yang sudah terbentuk dalam diri yang bersumber dari aktivitas sehari-hari, maka miskonsepsi akan terbentuk. Motivasi sebagai kekuatan mental dan sebagai penggerak belajar harus terus ditumbuh kembangkan pada siswa secara kontinyu sehingga hasil belajar yang dicapai sangat memuaskan dan miskonsepsi siswa menjadi nihil.

Miskonsepsi atau kesalahan konsep siswa pada pembelajaran fisika jika dibiarkan akan berefek lanjut pada level pendidikan siswa berikutnya (Fakhruddin, Azizahwati, \& Rahmi, 2012). Prakonsepsi, proses pembelajaran guru yang memtoivasi siswa belajar turut memegang peran dalam mempengaruhi perubahan miskonsepsi siswa (Yuliati, 2017). Analisis kontribusi pengetahuan awal dan motivasi belajar terhadap perubahan miskonsepsi siswa perlu dilakukan. Penelitian ini bertujuan (1) menganalisis kontribusi pengetahuan awal terhadap miskonsepsi siswa dalam pelajaran fisika, (2) menganalisis kontribusi motivasi belajar terhadap miskonsepsi siswa dalam pelajaran fisika, dan (3) menganalisis kontribusi pengetahuan awal dan motivasi siswa terhadap miskonsepsi yang dialaminya dalam pelajaran fisika.

\section{METODE PENELITIAN}

Jenis penelitian yang digunakan adalah penelitian korelasional, dimana peneliti bermaksud untuk mengungkap derajat keterhubungan antar variabel. Populasi dalam penelitian ini adalah semua siswa kelas X SMA di Kecamatan Nangapandayakni SMA Negeri 1 Nangapanda, SMAS Karya Nangapanda dan MAS Al IklasAnaraja. Jumlah populasi dalam penelitian ini adalah 222 orang. Sampel dipilih dengan menggunakan teknik "Proporsional random sampling". Secara keseluruhan jumlah sampel yang digunakan adalah 85 orang.

Data yang dikumpulkan dalam penelitian ini adalah data pengetahuan awal, motivasi belajar, dan miskonsepsi. Untuk mengumpulkan data pengetahuan awal dan miskonsepsi siswa, digunakan tes yang sama yaitu tes pemahaman konsep fisika yang disusun oleh penulis sendiri. Beberapa cara yang digunakan untuk menggali miskonsepsi siswa adalah pemberian soal open-ended, soal pilihan ganda, tes diagnotik bertingkat, tes mengambar. Tes hubungan kata, tes perubahan konseptual, inventaris konsep dan tes diagnostik secara daring (Patil et al., 2019).

Pokok bahasan yang digunakan sebagai sumber penyusunan instrument pemahaman konsep adalah listrik dinamis dengan jumlah soal yang disusun sebanyak 30 soal. Dipilihnya pokok bahasan ini karena hasil belajar yang dicapai siswa sangat rendah. Sedangkan data motivasi belajar dikumpulkan dengan menggunakan kuisioner motivasi yang diadaptasi dari Glynn \& Koballa, (2006). Instrument motivasi belajar dikembangan dari indikator "(1) hasrat dan keinginan berhasil (2) Adanya dorongan dan kebutuhan dalam belajar (3) Adanya harapan dan cita-cita masa depan (4) Adanya penghargaan dalam belajar (5) Adanya kegiatan yang menarik dalam belajar dan (6) Adanya lingkungan belajar yang kondusif" (Uno, 2021). Dari 6 indikator Motivasi Belajar siswa, penulis kembangkan kedalam 30 pernyataan.

Sebelum instrument tes pemahaman konsep digunakan, dilakukan terlebih dahulu uji validitas dan realibilitas. Validitas isi dan butir adalah uji validitas yang telah dilakukan. Validitas isi dilakukan oleh ahli dan dianalisis menggunakan formula Gregory (Gregory, 2000). Hasil analisis uji validitasisi/konten untuk aspek pemahaman konsep fisika sebesar 0,880 yang berarti kategori sangat tinggi. Sedangkan validitas isi untuk aspek motivasi belajar sebesar 1 berarti kategori sangat tinggi. Untuk uji validitas butir, kedua instrument menggunakan uji product moment (rxy) dan dianalisis menggunakan bantuan program IBM SPSS 20 for windows. Hasil analisis 
menunjukanbahwa10 item yang direvisi dengan indeks validitas berada pada rentang dari $r=$ 0,18 sampai dengan $r=0,28,20$ item yang valid dengan indeks validitas berada pada rentang dari $r=0,30$ sampai dengan $r=0,64$. Untuk aspek motivasi belajar diperoleh 30 item yang konsisten dengan indeks validitas bergerak dari $r=0,34$ sampai dengan $r=0,62$. Sedangkan untuk realibilitas butir, kedua instrument diuji menggunkan koefisien Alpha Cronbach yang dianalisis dengan bantuan program SPSS 20.0 for Windows. Hasil analisis menunjukan (1) Data pemahaman konsep fisika diperoleh koefisien reliabilitas $=0,805$ berkualifikasi sangat tinggi. (2) Data motivasi belajar diperoleh koefisien reliabilitas sebesar 0,921 berkualifikasi sangat tinggi.

Sesuai rumusan masalah yang ada maka data dianalisis menggunakan analisis jalur untuk mengetahui kontribusi antara pengetahuan awal dan motivasi belajar terhadap miskonsepsi fisika siswa. Untuk menguji hipotesis penelitian akan digunakan uji F melalui teknik regresi.

Dalam penelitian ini diajukan tiga hipotesis yakni 1) terdapat kontribusi pengetahuan awal terhadap miskonsepsi siswa dalam pelajaran fisika kelas $X$ semester genap Kecamatan Nangapanda 2). bahwa terdapat kontribusi motivasi belajar terhadap miskonsepsi yang dialami siswa kelas $X$ semester genap SMA di Kecamatan Nangapanda. 3). Secara Bersama-sama terdapat kontribusi pengetahuan awal dan motivasi belajar terhadap miskonsepsi yang dialami siswa kelas $X$ semester genap SMA di Kecamatan Nangapanda.

Sebanyak tiga hipotesis yang diajukan dalam penelitian ini. Untuk menguji ketiga hipotesis digunakan uji $\mathrm{F}$ melalui analisis regresi. Pengujian antar subjek yang didasarkan terhadap angka signifikansi dari nilai statistik yang diperoleh. Angka signifikansi (p) $<$ 0,05 mengindikasikan $\mathrm{H}_{0}$ ditolak sehingga terdapat kontribusi variabel bebas terhadap variabel terikat. Taraf signifikansi $5 \%$ sebagai dasar pengujian hipotesis.

\section{HASIL DAN PEMBAHASAN}

Penelitian ini telah berhasil menemukan data tentang kontibusi pengetahuan awal dan motivasi belajar terhadap miskonsepsi. Tabel 1 adalah deskripsi data miskonsepsi, pengetahuan awal dan motivasi belajar siswa. Tabel 2 adalah hasil pengujian normalitas data penelitian. Tabel 3 adalah hasil analisis regresi.

Tabel 1. Deskripsi Data Miskonsepsi, Pengetahuan Awal dan Motivasi Belajar

\begin{tabular}{lccccc}
\hline Variabel & N & Minimum & Maximum & Mean & SD \\
\hline Miskonsepsi & 85 & 1.00 & 15.00 & 8.27 & 3.242 \\
\hline Pengetahuan Awal & 85 & 19.00 & 45.00 & 32.40 & 6.501 \\
\hline Motivasi Belajar & 85 & 68.00 & 141.00 & 110.52 & 13.500 \\
\hline
\end{tabular}

Tabel 1 menunjukkan capaian skor masing masing variabel. Berdasarkan data hasil uji pemahaman konsep fisika yang dilakukan di awal materi pembelajaran dan selesai pembelajaran serta hasil kuisioner motivasi yang dilakukan di 3 SMA di Kecamatan Nangapanda yaitu SMA Negeri 1 Nangapanda, SMAS Karya Nangapanda, dan MAS Al Ikhlas Anaraja, ternyata skor rata-rata pengetahuan awal pada masing-masing sekolah adalah sebesar 32.4, skor rata-rata motivasi belajar pada masing-masing sekolah adalah sebesar 110.52, dan skor rata-rata miskonsepsi yang dialami pada masing-masing sekolah adalah sebesar 8.27. Fakta ini mengindikasikan bahwa pengetahuan awal siswa terhadap pelajaran fisika di di Kecamatan Nangapanda adalah tergolong sedang, motivasi belajar siswa terhadap pelajaran fisika Kecamatan Nangapanda adalah tergolong tinggi, dan miskonsepsi yang dialami siswa terhadap pelajaran fisika di Kecamatan Nangapanda adalah tergolong dalam kategori sedang.

Tabel 2. Uji Normalitas Data

\begin{tabular}{lllll}
\hline Variabel & $\mathbf{N}$ & SD & $\mathbf{Z}$ & $\boldsymbol{P}$ \\
\hline Pengetahuan awal terhadap miskonsepsi & 85 & 2.184 & 0.656 & 0.752 \\
\hline Motivasi belajar terhadap miskonsepsi & 85 & 2.084 & 1.036 & 0.782 \\
\hline Pengetahuan awal dan motivasi belajar terhadap miskonsepsi & 85 & 1.820 & 0.675 & 0.234 \\
\hline
\end{tabular}

Tabel 1 menjelaskan bahwa data hasil penelitian adalah normal. Ketiga data yaitu pengetahuan awal terhadap miskonsepsi, motivasi belajar terhadap miskonsepsi, dan secara Bersama-sama pengetahuan awal dan motivasi belajar terhadap miskonsepsi memiliki distribusi normal. Hal ini terlihat dari Nilai $P>$ 0.05 . Data temuan selanjutnya dapat dianalisis regresi. Tabel 3 menghadirkan hasil analisis regresi. 
Tabel 3. Hasil Analisis Regresi

\begin{tabular}{lcccc}
\hline \multicolumn{1}{c}{ Variabel } & Persamaan Regresi & $\boldsymbol{P}$ & $\begin{array}{c}\text { Koefisien } \\
\text { Korelasi (R) }\end{array}$ & $\begin{array}{c}\text { Koefisien } \\
\text { Determinasi } \\
\left(\mathbf{R}^{2}\right)\end{array}$ \\
\hline $\begin{array}{l}\text { Pengetahuan } \\
\text { awal terhadap } \\
\text { miskonsepsi }\end{array}$ & $\mathrm{Y}=20.209-0.368\left(\mathrm{X}_{1}\right)$ & 0.000 & 0.739 & 0.546 \\
\hline $\begin{array}{l}\text { Motivasi belajar } \\
\text { terhadap } \\
\text { miskonsepsi }\end{array}$ & $\mathrm{Y}=28.596-0.184\left(\mathrm{X}_{2}\right)$ & 0.00 & 0.766 & 0.587 \\
\hline $\begin{array}{l}\text { Pengetahuan } \\
\text { awal dan } \\
\text { motivasi belajar } \\
\text { terhadap } \\
\text { miskonsepsi }\end{array}$ & $\mathrm{Y}=28.075-0.207\left(\mathrm{X}_{1}\right)-0.119$ & 0.00 & 0.828 & 0.685 \\
\hline
\end{tabular}

Hasil penelitian menunjukkan bahwa kontribusi pengetahuan awal terhadap miskonsepsi sebesar 54.6\% $\left(R^{2}=0.546\right)$. Hubungan antara pengetahuan awal terhadap miskonsepsi adalah sangat kuat, itu diindikasikan dengan $R=0.739$. Persamaan regresi menunjukkan bahwa setiap kenaikan satu poin pengetahuan awal, maka akan menurunkan miskonsepsi sebesar 0.368 . temuan ini mengindikasikan bahwa semakin baik pengetahuan awal siswa, maka terjadinya miskonsepsi siswa akan semakin kecil. Temuan tentang kontribusi motivasi belajar terhadap miskonsepsi menunjukkan bahwa motivasi memiliki sumbangsi sebesar 58.7\% $\left(R^{2}=0.587\right)$. Lebih dari setengah miskonsepsi siswa dipengaruhi oleh motivasi belajar siswa. Kekuatan hubungan antara kedua variabel ini adalah sangat kuat yaitu 0.766. Dari persamaan regresi yang ada mengungkap bahwa setiap kenaikan satu poin motivasi belajar siswa, maka akan mengurangi miskonsepsi siswa terharap materi pelajaran sebesar 0.184 . Secara bersama-sama variabel Pengetahuan awal dan motivasi belajar memiliki kontribusi terhadap miskonsepsi siswa. Besar kontribusinya adalah sebesar $68.5 \%$ $\left(R^{2}=0.685\right)$.

Temuan dalam penelitian ini konsisten dengan hasil-hasil penelitian sebelumnya, seperti yang dilakukan oleh (Yuliati, 2017) dan Repi, (2006), menemukan bahwa pengetahuan awal berdampak signifikan terhadap miskonsepsi siswa. Turkmen \& Usta, (2007), mengungkapkan bahwa motivasi belajar menjadi penyebab tinggi rendahnya miskonsepsi yang dialami siswa. Temuan dalam penelitian ini juga sejalan dengan hasil penelitian Santyasa, (2004) yang mengungkapkan bahwa pengetahuan awal, persepsi siswa terhadap pesan pembelajaran, dan motivasi berprestasi siswa berhubungan secara positif dan signifikan dengan hasil belajar.
Hasil analisis sumbangan efektif pengetahuan awal terhadap miskonsepsi sebesar $54.6 \%$, artinya pengetahuan awal mampu menjelaskan miskonsepsi sebesar $54.6 \%$. Sumbangan efektif motivasi belajar terhadap miskonsepsi sebesar $58.7 \%$, artinya motivasi belajar mampu menjelaskan miskonsepsi sebesar $58.7 \%$. Sumbangan efektif pengetahuan awal dan motivasi belajar terhadap miskonsepsi sebesar $68.5 \%$, artinya pengetahuan awal dan motivasi belajar mampu menjelaskan miskonsepsi sebesar $68.5 \%$.

Meskipun pengetahuan awal dan motivasi belajar sangat berpengaruhi terhadap miskonsepsi siswa, namun belum secara optimal dapat menjamin rendahnya miskonsepsi yang dialami siswa. Ketidaksesuaian pembekajaran yang dilakukan oleh guru diduga sebagai salah satu faktor penyebab miskonsepsi. Pembelajaran yang tidak sesuai dan pengabaian terhadap pengetahuan awal yang dimiliki siswa menyebabkan pembentukan pengetahuan baru terganggu. Konflik kognitif terjadi ketika penerimaa informasi baru karena pengetahuan awal diabaikan. Efek dari pengabaian konflik kognitif menyebabkan miskonsepsi siswa. Namun konflik kognitif yang dikontrol misalnya pemberian pembelajaran berbasis konflik kognitif menyebakan penuruna miskonsepsi (Adnyani, Sadia, \& Natajaya, 2013; Handhika, Kurniadi, \& Muda, 2014). Motivasi belajar yang tinggi dapat menumbuhkan dorongan untuk belajar, sehingga terbina keinginan dalam diri untuk selalu mencari dan memperoleh informasi yang akurat dan benar.

Implikasi temuan penelitian ini adalah pembelajaran fisika dapat memberikan hasil belajar yang optimal jika siswa tidak lagi memiliki miskonsepsi. Menghilangkan miskonsepsi yang dialami siswa didasarkan pada paradigma konstruktivisme. Pengetahuan awal siswa merupakan sebagai kerangka dasar untuk membentuk pengetahuan baru setelah 
melalui proses belajar. Karena itulah pengetahuan awal siswa harus diperhatikan pada saat pembelajaran. Karena dengan mengetahui pengetahuan awal siswa, guru dapat memilih teknik-teknik yang baik untuk mengubah konsepsi awal siswa yang masih bersifat miskonsepsi. Santyasa, (2004) mengungkapkan bahwa motivasi intrinsik para siswa berkembang karena pengetahuan awal siswa. Artinya, pengetahuan mendukung meningkatnta motivasi siswa untuk dapat berprestasi.

Motivasi belajar siswa dapat dijadikan bahan pertimbangan dalam merencanakan, mendesain dan melaksanakan pembelajaran. Menurut Sardiman, (2005) "Motivation is an essensial condition of learning", artinya motivasi sangat diperlukan dalam aktivitas belajar. Hasil belajar mencapai hasil optimal jika siswa memiliki motivasi yang tinggi. Makin besar motivasi memberikan keberhasilan belajar yang besar pula. Pengetahuan awal dan motivasi belajar adalah dua unsur lingkungan belajar konstruktivis yang dapat dijadikan pedoman untuk menyusun model pembelajaran yang mampu meminimalisasi miskonsepsi siswa. Pembelajaran berbasis kebutuhan siswa perlu diterapkan untuk memotivasi siswa (Andersson \& Palm, 2018).

Beberapa strategi yang digunakan untuk menurunkan miskonsepsi siswa adalah memilih model pembelajaran yang berbasis student center seperti menggunakan model pembelajaran problem solving (Suparno, 2013), model pembelajaran inquiry training (Lelasari, Yohanita, \& Damopolii, 2021; Mandasari, Iwan, \& Damopolii, 2021; Sani \& Aulia, 2018), strategi perubahan konseptual, (Chavan \& Patankar, 2016; Eryilmaz, 2002; Suparno, 2013), Metode peta konsep (Chavan \& Patankar, 2016; Patil et al., 2019; Suparno, 2013), konsep kartun (Chavan \& Patankar, 2016), teknik bermain peran; pendekatan saintifik, metode mind map, wawancaran diagnosis, Briging analogi, dan simulasi computer diskusi kelompok, pembelajaran kooperatif dibantu animasi (Bahtiar, Kafrawi, \& Yeni, 2020; Suparno, 2013). Adanya kontribusi pengetahuan awal dan motivasi terhadap miskonsepsi siswa, maka dalam pembelajaran harus dapat memperhatikan kedua variable ini untuk mengurangi miskonsepsi siswa. rancangan pembelajaran yang baik akan mengubah pengetahuan awal siswa yang mengandung miskonsepsi menjadi pengetahuan yang baru yang benar. Hasil riset ini bermanfaat sebagai data awal untuk merencanakan pembelajaran selanjutnya dalam pembelajaran fisika.

\section{SIMPULAN DAN SARAN}

Berdasarkan hasil penelitian dapat dikemukakan tiga buah simpulan sebagai berikut: 1) Terdapat kontribusi pengetahuan awal terhadap miskonsepsi yang dialami siswa kelas X SMA di Kecamatan Nangapanda sebesar $54.6 \% \quad(p<0.05), 2)$, terdapat kontribusi motivasi belajar terhadap miskonsepsi yang dialami siswa kelas X SMA dikecamatan Nangapanda sebesar 58.7\% ( $p<$ $0.05)$, 3) Terdapat kontribusi pengetahuan awal dan motivasi belajar terhadap miskonsepsi yang dialami siswa kelas X SMA di Kecamatan Nangapanda sebesar $68.5 \%(p<0.05)$.

Saran untuk penelitian lanjutan adalah dapat meneliti tentang penggunaan pembelajaran yang dapat menumbuhkan motivasi siswa untuk belajar fisika dan pembelajaran yang dapat mengubah pengetahuan awal siswa menjadi pengetahuan yang baru yang benar sehingga dapat mereduksi miskonsepsi siswa.

\section{DAFTAR RUJUKAN}

Adnyani, N. W., Sadia, I. W., \& Natajaya, I. W. (2013). Pengaruh strategi pembelajaran konflik kognitif terhadap penurunan miskonsepsi fisika ditinjau dari gaya kognitif siswa kelas $X$ di SMa Negeri 1 Berandem. Jurnal Administrasi Pendidikan Indonesia, 4(1), $\quad 1-11$. https://doi.org/10.23887/japi.v4i1.956

Andersson, C., \& Palm, T. (2018). Reasons for teachers' successful development of a formative assessment practice through professional development--a motivation perspective. Assessment in Education: Principles, Policy \& Practice, 25(6), $\quad$ 576-597. https://doi.org/10.1080/0969594X.2018 .1430685

Avila, E. C., \& Genio, A. M. G. J. (2020). Motivation and learning strategies of education students in online learning during pandemic. Psychology and Education Journal, 57(9), 1608-1614. https://doi.org/https://doi.org/10.17762/ pae.v57i9.506

Bahtiar, B., Kafrawi, M., \& Yeni, S. (2020). Pengaruh model pembelajaran kooperatif tipe stad menggunakan media film animasi terhadap motivasi dan hasil belajar siswa di MTs. AlIntishor Sekarbela. ORBITA: Jurnal Kajian, Inovasi Dan Aplikasi Pendidikan Fisika, 6(2), 207. https://doi.org/10.31764/orbita.v6i2.28 76

Baransano, A. Y., Yohanita, A. M., \& Damopolii, 
I. (2017). Penerapan model pembelajaran picture and picture untuk meningkatkan hasil belajar biologi siswa kelas XI IPA SMA YABT Manokwari. Prosiding Seminar Nasional MIPA II Universitas Papua Tahun 2017, 273-280. Jakarta: Sinar Grafika.

Bhure, M., Welu, F., See, S., \& Ota, M. K. (2021). The effort to enhance pupils cognitive learning achievement using contextual teaching and learning approach. Journal of Research in Instructional, 1(1), 13-22. https://doi.org/10.30862/jri.v1i1.3

Brown, D. E. (1992). Using examples and analogies to remediate misconceptions in physics: Factors influencing conceptual change. Journal of Research in Science Teaching, 29(1), 17-34.

https://doi.org/10.1002/tea.366029010 4

Carey, S., Evans, R., Honda, M., Jay, E., \& Unger, C. (1989). 'An experiment is when you try it and see if it works': a study of grade 7 students' understanding of the construction of scientific knowledge. International Journal of Science Education, 11(5), 514-529.

https://doi.org/10.1080/095006989011 0504

Chan, M. I. H., Septia, E. A., Febrianti, K., \& Desnita, D. (2021). Efektivitas model pembelajaran terhadap peningkatan pemahaman konsep fisika siswa SMA: Meta-analisis. ORBITA: Jurnal Kajian, Inovasi Dan Aplikasi Pendidikan Fisika, 7(2), 238-245. https://doi.org/10.31764/orbita.v7i2.57 14

Chavan, R., \& Patankar, D. P. (2016). Constructivist strategies for minimization of science misconceptions among school students. Interdisciplinary National Conference on Researches and Experiments in Constructivist Pedagogy, 1-7. Kolhapur.

Dahar, R. W. (2011). Teori-teori belajar dan pembelajaran. Jakarta: Erlangga.

Duit, R. (1996). Preconception \& misconception. In International Encyclopedia of Developmental and Instructional Psychology. Pergamon.

Eryilmaz, A. (2002). Effects of conceptual assignments and conceptual change discussions on students' misconceptions and achievement regarding force and motion. Journal of Research in Science Teaching, 39(10), 1001-1015.

https://doi.org/10.1002/tea.10054

Fakhruddin, F., Azizahwati, A., \& Rahmi, Y. (2012). Analisis penyebab miskonsepsi siswa pada pelajaran fisika di kelas XII SMA/MA Kota Duri. Jurnal Pendidikan Matematika, 3(1), 87-98. https://doi.org/10.36709/jpm.v3i1.1988

Glynn, S. M., \& Koballa, T. R. J. (2006). Motivation to learn in college science. In J. J. Mintzes \& W. H. Leonard (Eds.), Handbook of College Science Teaching (pp. 25-32). Arlington, VA: National Science Teachers Association Press.

Gregory, R. J. (2000). Psycologycal testing, history, principles, and applications. Boston: Allyn \&Bacon, Inc.

Hammer, D. (1996). More than misconceptions: Multiple perspectives on student knowledge and reasoning, and an appropriate role for education research. American Journal of Physics, 64(10), 1316-1325. https://doi.org/10.1119/1.18376

Handhika, J., Kurniadi, E., \& Muda, I. (2014). Pengembangan media pembelajaran bermuatan konflik kognitif untuk mengurangi dugaan miskonsepsi pada matakuliah fisika dasar. Jurnal Materi Dan Pembelajaran Fisika (JMPF), 4(2), 8-13.

Harso, A. (2018). Profil miskonsepsi siswa dalam pembelajaran fisika kelas X SMA Se-kecamatan Nangapanda. OPTIKA: Jurnal Pendidikan Fisika, 2(1), 38-43.

Kuczmann, I. (2017). The structure of knowledge and students' misconceptions in physics. AIP Conference Proceedings, 050001. https://doi.org/10.1063/1.5017454

Kurniawan, R. P., Damopolii, I., \& Sirait, S. H. K. (2021). The correlation between biology teacher learning strategies during the COVID-19 pandemic on student motivation. In AECON (pp. 299-305).

Lelasari, T., Yohanita, A. M., \& Damopolii, I. (2021). Effect of inquiry science learning on students' metacognitive skill. Journal of Research in Instructional, 1(1), 53-60. https://doi.org/10.30862/jri.v1i1.12

Mandasari, F., Iwan, I., \& Damopolii, I. (2021). The relationship between science process skills and biology learning outcome. Journal of Research in Instructional, 1(1), 23-32. https://doi.org/10.30862/jri.v1i1.9 
Nurmaya, Y., Susilawati, S., Zuhdi, M., \& Hikmawati, H. (2021). Pengembangan perangkat pembelajaran model inkuiri terbimbing pada materi alat-alat optik untuk meningkatkan penguasaan konsep fisika. ORBITA: Jurnal Kajian, Inovasi Dan Aplikasi Pendidikan Fisika, $7(1)$, 147. https://doi.org/10.31764/orbita.v7i1.38 35

Patil, S. J., Chavan, R. L., \& Khandagale, V. S. (2019). Identification of misconceptions in science: Tools, techniques \& skills for teachers. Aarhat Multidisciplinary International Education Research Journal (AMIERJ), 8(2), 466-472.

Perkins, D. N., \& Simmons, R. (1988). Patterns of misunderstanding: An integrative model for science, math, and programming. Review of Educational Research, 58(3), 303-326. https://doi.org/10.3102/003465430580 03303

Raiman, M., Liu, A. N. A. M., \& Wolo, D. (2021). Investigation of students' motivation to learn science while studying from home during a pandemic. Journal of Research in Instructional, 1(1), 33-42. https://doi.org/10.30862/jri.v1i1.10

Repi, R. A. (2006). Profil kemampuan awal dan miskonsepsi IPA biologi siswa SMA SeKota Manado. Jurnal Pendidikan Matematika Dan Sains, 1(1), 1-47.

Ruto, R., Mema, A., Nduru, M. P., \& Ota, M. K. (2021). Contextual teaching and learning approach in social science: its role to encourage pupils' cognitive learning achievement. Journal of Research in Instructional, 1(1), 43-52. https://doi.org/10.30862/jri.v1i1.11

Sadia, I. W. (1997). Efektifitas strategi konflik kognitif dalam mengubah miskonsepsi siswa (Suatu studi kuasi eksperimental dalam pembelajaran konsep energi, usaha, dan gaya di SMU N 1 Singaraja). Singaraja.

Sani, R. A., \& Aulia, R. (2018). Upaya mengatasi miskonsepsi siswa dengan menggunakan model pembelajaran inquiry training pada materi pokok momentum dan impuls di kelas X SMA Negeri 3 Binjai T.P 2017/2018. Jurnal Ikatan Alumni Fisika Universitas Negeri Medan, 4(3), 16-21. https://doi.org/doi.org/10.24114/jiaf.v4i 3.10913

Santyasa, I. W. (2004). Pengaruh model konflik kognitif dan model siklus belajar untuk memperbaiki miskonsepsi siswa dalam pembelajaran fisika. Jurnal Pendidikan
Dan Pengajaran IKIP Negeri Singaraja, 36(3), 40-58.

Santyasa, I. W. (2012). Pembelajaran Inovatif. Seri buku buku ajar perguruan tinggi. Singaraja: Undiksha Press.

Saputri, D. F., \& Nurussaniah, N. (2015). Penyebab miskonsepsi pada optika geometris. Prosiding Seminar Nasional Fisika (E-Journal) SNF2015, 4, 33-36.

Sardiman. (2005). Interaksi \& Motivasi Belajar Mengajar. Jakarta: Raja Grafindo Persada.

Slameto. (2003). Belajar dan Faktor-Faktor yang Mempengaruhinya. Jakarta: Rineka Cipta.

Suparno, P. (2013). Miskonsepsi dan perubahan konsep dalam pendidikan fisika. Jakarta: Gramedia Widiasarana Indonesia.

Sutrisno, A. D. (2019). Survey pemahaman konsep dan identifikasi miskonsepsi siswa SMA pada materi kinematika gerak. WaPFi (Wahana Pendidikan Fisika), $\quad 4(1), \quad 106$. https://doi.org/10.17509/wapfi.v4i1.157 96

Turkmen, H., \& Usta, E. (2007). The role of learning cycle approach overcoming misconceptions in science. Kastamonu Education Journal, 15(2), 491-500.

Uno, H. B. (2021). Teori motivasi dan pengukurannya: Analisis di bidang pendidikan. Bumi Aksara.

Vosniadou, S., loannides, C., Dimitrakopoulou, A., \& Papademetriou, E. (2001). Designing learning environments to promote conceptual change in science. Learning and Instruction, 11(4-5), 381419. https://doi.org/10.1016/S09594752(00)00038-4

Yenilmez, K., \& Cemrek, F. (2008). Teaching motivation of the students in secondary teacher training schools in Turkeyez, K \& F. Cemrek. International Journal of Environmental \& Science Education, 3(2), 82-88.

Yuliati, Y. (2017). Miskonespsi siswa pada pembelaran IPA dan Remediasinya. Jurnal Bio Educatio, 2(2), 50-58. https://doi.org/10.31949/be.v2i2.1197

Yurida, Y., Damopolii, I., \& Erari, S. S. (2021). Hubungan antara kreativitas guru dengan motivasi belajar sains siswa selama pandemic COVID-19. Prosiding SNPBS (Seminar Nasional Pendidikan Biologi Dan Saintek), 146-152. 